\title{
Research Paper Spatial market integration and short-run dynamics under varying data periods: Evidence from maize markets in Karnataka, India
}

口 CHARLES C. NDLOVU AND BALACHANDRA K. NAIK

See end of the paper for authors' affiliations

Correspondence to : CHARLES C. NDLOVU Department of Agribusiness Management, University of Agricultural Sciences, DHARWAD (KARNATAKA) INDIA

Email: cmndlov289@ gmail.com

Paper History :

Received : 24.02.2016;

Revised : 28.07.2016;

Accepted : 22.08 .2016
Abstract : The paper examined the dynamics of spatial integration and speed of price adjustment to long-run equilibrium in maize markets in Karnataka across different data periods. Monthly time series data from major maize markets in Karnataka were split into three time periods, 2002-2008, 2009-2015 and 2002-2015 and subjected to rigorous analysis using Johansen cointegration technique and vector error correction models. The results show that both market integration and speed of adjustments vary depending on the data period selected. Four market pairs were segmented during 2002-08 and three markets in 2009-15 periods. These segmented markets are concealed in 2002-15 period as all markets are found to be integrated. Davanagere APMC market takes central and leadership position in price formulation and transmission in the examined maize market across all three periods. Analysis of speed of adjustment has shown that with respect to Davanagere APMC market, all other markets respond more rapidly during 2002-08 (25\%-90\%) on a monthly basis than during 2002-15 (14\%-66\%). This finding is stands in sharp contrast to cointegration results which revealed that market integration is high during 2002-15 than 2002-2008 implying high price information flow. Thus, a great deal of caution is required before making any generalized conclusion regarding market integration and price transmission based on one data period. These findings imply that appropriate agricultural marketing policy measures can improve market integration and flow of price information over time.

KEY Words : Agricultural markets, Error correction, Market integration, Price analysis

HOW TO CITE THIS PAPER : Ndlovu, Charles C. and Naik, Balachandra K. (2016). Spatial market integration and short-run dynamics under varying data periods: Evidence from maize markets in Karnataka, India . Internat. Res. J. Agric. Eco. \& Stat., 7 (2) : 208-216, DOI : 10.15740/HAS/IRJAES/7.2/208-216. 